\title{
Enzyme-Histochemical Demonstration of Intralobular Lymphatic Vessels in the Mouse Thymus*
}

\author{
Seiji KATo \\ Department of Anatomy, Medical College of Oita, Oita, Japan
}

Received August 23, 1989

Summary. Intralobular lymphatic vessels in the mouse thymus were demonstrated enzyme-histochemically by combined light and electron microscopy. In sections reacting to both $5^{\prime}$-nucleotidase $\left(5^{\prime}-\mathrm{Nase}\right)$ and alkaline phosphatase (ALPase), the intralobular lymphatic vessels were identified as irregularly shaped spaces with strong $5^{\prime}$-Nase activity. The lymphatic vessels were closely associated with the branches of ALPase-positive intralobular arteries and veins. The initial lymphatics, which presumably originate from the perivascular spaces, were $5^{\prime}$-Nase positive. The distribution and intensity of the $5^{\prime}$-Nase activity in the lymphatic vessels revealed by light microscopy correlated well with those by backscattered image electron microscopy. The backscattered image scanning electron microscopy of the same area as observed under a light microscope more clearly highlighted the peculiar contours of lymphatic endothelial cells . Transmission electron microscopy showed that specific reaction product of the 5 -Nase after incubation in a medium containing L-tetramisole was predominantly localized on the outer surface of the lymphatic endothelial cell membranes.

The enzyme $5^{\prime}$-nucleotidase $\left(5^{\prime}\right.$-Nase), which is associated with the plasma membrane and catalizes the diphosphorylation of $5^{\prime}$-nucleotide monophosphatates, has been widely used as an enzyme marker for plasma membranes. In early experiments VETTER (1970) and HEUSERMANN (1979) suggested that $5^{\prime}$ Nase activity was higher in the wall of lymphatics than in blood vessels. In a more recent study, WER NER, SHÜNKE and TILLMANN (1987) applied this enzymic property to demonstrate lymphatics of the rat pharynx at the level of the light microscope, using a $5^{\prime}$-Nase-Alkaline phosphatase (ALPase) double staining method. The author (KATO and MiYAUCHI, 1989) employed this double staining method along with scanning and transmission electron microscopy to show the three-dimensional orientation of lymphatics in the mouse tongue in serial cryostat sections. The author (KATO, 1989, 1990) has also demonstrated that the use of $5^{\prime}$-Nase activity provides us with a satisfactory method to distinguish lymphatics from blood vessels in various mammalian tissues and that the backscattered image scanning electron microscopy is useful for enzyme histochemistry applied to tissue sections.

The distribution and the fine structure of thymic lymphatic vessels with special reference to their relationships to blood vessels has been studied in several mammalian species (SMITH, 1955; KoTANI et al., 1966, 1967; HWANG et al., 1974; OMORI, 1973; UsHIKI, 1986). Despite these observations, the existence of lymphatic vessels within thymic lobules and their morphological characteristics remain to be fully described. In a previous study (KATO, 1988), however, the author did successfully demonstrate histologically in the mouse thymus certain intralobular lymphatic vessels appearing as irregularly shaped spaces closely associated with branches of the intralobular artery and vein; he suggested that such lymphatics may originate initially from the perivascular spaces surrounding the postcapillary venules. In this context, the present study aims to demonstrate enzymehistochemically the intralobular lymphatic vessels, especially the initial lymphatics, and distinguish them from blood vessels in the same section by light and backscattered image scanning electron microscopy. The distribution and the fine structure of these lymphatics in relation to blood vessels were also studied by transmission electron microscopy.

${ }^{*}$ This paper is dedicated to Emeritus Professor M. KoTANI on the occasion of his retirement from Kumamoto University Medical School.

This study was supported in part by a research grant (No. 63304029, Prof. Dr. S. Uchino) from the Ministry of Education, Science and Culture, Japan. 


\section{MATERIALS AND METHODS}

Forty five thymuses of $8-20$ month-old BALB/c mice of both sexes were examined. The mice were anesthetized with diethyl ether and fixed by perfusion via the aorta (KATO and SchoEFL, 1989). The vascular bed was flushed out with $0.1 \mathrm{M}$ cacodylate buffer $(\mathrm{pH}$ 7.2) containing $7 \%$ sucrose and then fixed with $6 \%$ paraformaldehyde-1\% $\mathrm{CaCl}_{2}$ in the same buffer. Some vascular beds were filled with a mixture of colloidal carbon suspension (Pelikanwerke, Hannover, FRG).

\section{Light microscopy}

After perfusion, the thymus was excised and frozen at a temperature of $-20^{\circ} \mathrm{C}$. Frozen sections, $10-20$ $\mu \mathrm{m}$ in thickness, were cut in a cryostat (Sakura Coldtome CM-41, Sakura Seiki, Tokyo, Japan or Bright 5030 microtome, U.K.), mounted on albumin coated slides and air-dried. They were then immersed in the same fixative for $10 \mathrm{~min}$. After they had been washed in three changes of $0.1 \mathrm{M}$ cacodylate buffer, they were incubated for $30-60 \mathrm{~min}$ in a lead-based standard medium for $5^{\prime}$-Nase reaction according to the method by WACHSTEIN and MEISEL (1957) for light microscopy, as reported previously (KATO and MiYAUCHI, 1989; KATO, 1989, 1990). Briefly, the standard medium contains: $20 \mathrm{ml} 0.2 \mathrm{M}$ Tris-maleate buffer ( $\mathrm{pH} 7.2$ ); $25 \mathrm{mg}, 5^{\prime}$-adenosine monophosphate (AMP, sodium salt, Sigma); $5 \mathrm{ml} 0.1 \mathrm{M} \mathrm{MgSO}_{4} ; 3-4 \mathrm{~g}$ sucrose; $22 \mathrm{ml}$ distilled water; and $3 \mathrm{ml} 2 \% \mathrm{~Pb}\left(\mathrm{NO}_{3}\right)_{2}$ (Taab). To obtain the specific reaction for $5^{\prime}$-Nase activity, $10 \mathrm{mg}$ of L-tetramisole ( $1 \mathrm{mM}$, Sigma) as an inhibitor of nonspecific ALPase was added to the standard medium according to the method by WER . NER, SCHÜNKE and TILlMANN (1987). When demonstration of $5^{\prime}$-Nase activity was followed by ALPase reaction, the incubation mixture did not contain L-tetramisole. Following incubation in the medium, the sections for light microscopy were rinsed in distilled water and then immersed in $1 \%$ yellow ammonium sulfide solution for 2 min before examination.

Sections for the ALPase reaction were incubated for 20-60 min at room temperature according to the azo-dye method (BURSTONE, 1962). Briefly, $40 \mathrm{mg}$ of naphthol AS-MX phosphate (disodium salt, Sigma) was dissolved in $2 \mathrm{ml}$ of $\mathrm{NN}^{\prime}$-dimethylformamide and added to $40 \mathrm{ml}$ of $0.1 \mathrm{M}$ Tris- $\mathrm{HCl}$ buffer $(\mathrm{pH} \mathrm{7.2)}$ containing $40 \mathrm{mg}$ of fast blue BB (Sigma). The following controls were used: 1) incubation without substrate (AMP or naphthol AS-MX phosphate); 2) inhi- bition of 5 '-Nase and ALPase activities with $\mathrm{NiCl}_{2}$ $(50 \mathrm{mM})$ and L-tetramisole $(5 \mathrm{mM})$ respectively before being incubated in the reaction medium; and 3) inhibition of both enzymes with treatment at $60^{\circ} \mathrm{C}$ for 60 min before incubation. After incubation, the sections were thoroughly rinsed in distilled water and mounted in glycerin for light microscopy.

\section{Scanning electron microscopy}

After examining the sections with the light microscope, they were dehydrated in ascending concentrations of ethanol and dried according to the $t$ butylalcohol freeze-drying method, by WHEELER, Gavin and Seelye (1975) and Inoué and Osatake (1988). Dried specimens were mounted on an aluminum stub with carbon paste. In order to prevent artifacts due to charging, the specimens were coated with carbon for backscatter electron images (BEI) or with gold for secondary electron images (SEI) to a thickness of about $20 \mathrm{~nm}$.

The specimens were examined in a Hitachi S-800 SEM equipped with a GM type 30 backscattered electron detector. For BEI observations, the working distance was approximately $15 \mathrm{~mm}$, the objective aperture $200 \mu \mathrm{m}$, the specimen stage tilt $0^{\circ}$, the accelerating voltage 15 or $20 \mathrm{kV}$ and the probe current $10^{-11}$ to $10^{-9} \mathrm{~A}$.

\section{Transmission electron microscopy (TEM)}

Following perfusion or immersion fixation, the specimens were excised, sliced and immersed in the same fixative for $30 \mathrm{~min}$. The slices were rinsed in $0.1 \mathrm{M}$ cacodylate buffer ( $\mathrm{pH} 7.2$ ) containing $7 \%$ sucrose and incubated for $30 \mathrm{~min}$ at $37^{\circ} \mathrm{C}$ in the reaction medium according to the lead-based method by UUSITALO and KARNOVSKY, 1977). Sections incubated in the ceriumbased medium of ROBINSON and KARNOVSKY (1983) were also examined. Briefly, this medium contains: $20 \mathrm{ml} 0.2 \mathrm{M}$ Tris-maleate buffer (pH 7.4); $16 \mathrm{mg}$ 5'AMP; $4 \mathrm{ml} 0.02 \mathrm{M} \mathrm{MgCl}_{2} ; 2 \mathrm{~g}$ sucrose; $12 \mathrm{ml}$ distilled water; and $4 \mathrm{ml} 0.02 \mathrm{M} \mathrm{CeCl}_{3}$. Both reaction media contained L-tetramisole $(1 \mathrm{mM})$ to obtain specific 5'-Nase activity for TEM. After incubation, the specimens were postfixed in a $2 \%$ osmium tetroxide $-0.5 \%$ potassium ferrocryanide solution in $0.1 \mathrm{M}$ cacodylate buffer $(\mathrm{pH} 7.2)$ for $1 \mathrm{~h}$ at $4^{\circ} \mathrm{C}$. They were dehydrated in ascending concentrations of ethanol and embedded in Spurr resin (Tabb) as reported previously (KATO and SCHOEFL, 1989). Ultrathin sections were cut with a diamond knife on a Reichert OmU4 ultramicrotome. Sections, stained or unstained with uranyl acetate, were examined in a JEM 100CX TEM. 


\section{RESULTS}

\section{Light microscopy}

In cryostat sections incubated in the standard medium for $5^{\prime}$-Nase reaction, the dark-brown or black lead sulfide reaction product was localized in the intralobular lymphatic vessels of the mouse thymus. In contrast, $5^{\prime}$-Nase activity in the blood vessels was significantly lower or absent (Fig. 1a). When sections were further incubated in the medium for ALPase reaction, the ALPase blue reaction product was restricted to blood vessels and clearly contrasted with the brown reaction product of $5^{\prime}$ Nase activity in lymphatic vessels (Fig. 1b). This reaction pattern for ALPase persisted unchanged regardless of whether or not the section was previously assayed for $5^{\prime}$-Nase. Figure 2a shows the distribution of $5^{\prime}$-Nase-positive lymphatics and ALPasepositive blood vessels in the thymus medulla. The lymphatic vessels showed a cobble stone-like staining pattern. It appeared to correspond to the contours of lymphatic endothelial cells (Fig. 2a). Figure 3a illustrates a $5^{\prime}$-Nase-positive lymphatic vessel adjoining the perivascular space (PVS) of a ALPase-positive postcapillary venule (PCV) in the medulla. The $5^{\prime}$ Nase activity is closely associated with the lymphatic, and the ALPase activity with the blood vessel. The PVS is $5^{\prime}$-Nase negative. No brown or black reaction product was seen in control sections preincubated in a substrate-free medium or treated at $60^{\circ}$ $\mathrm{C}$ for 60 min or with $\mathrm{NiCl}_{2}$.

a
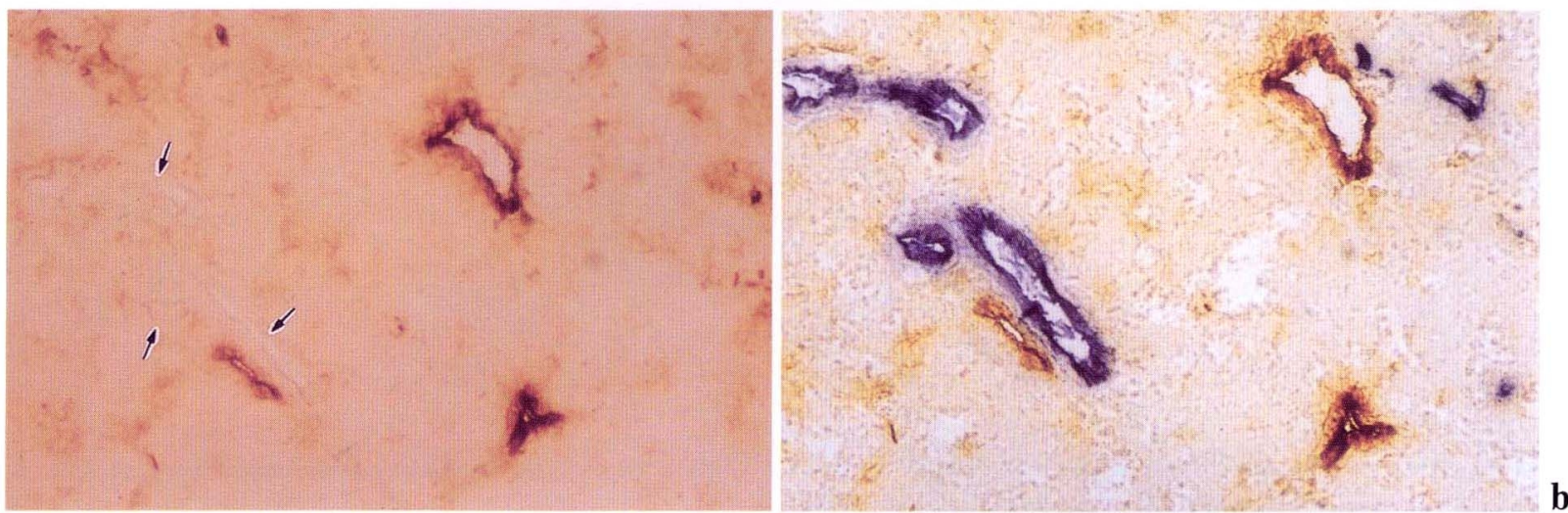

Fig. 1. Light (a, b) and BEI scanning electron (c) micrographs of a cryostat section $(10 \mu \mathrm{m})$ of the mouse thymus. a. $5^{\prime}$-Nase activity of the thymic medulla. Dark brown staining indicates a strong positive reaction for $5^{\prime}$-Nase activity in the walls of intralobular lymphatics. Blood vessels (arrows) show little or no activity. $\times 200$. b. The same section after additional incubation for ALPase. Blood vessels are ALPase-positive (blue) and contrast with the $5^{\prime}$-Nase reaction (dark brown) of the lymphatics. $\times 200$. c. BEI of the same section as shown in Figure 1b. The lymphatic walls are highlighted by backscattering from the reaction product. Arrows indicate blood vessels. $\times 250$

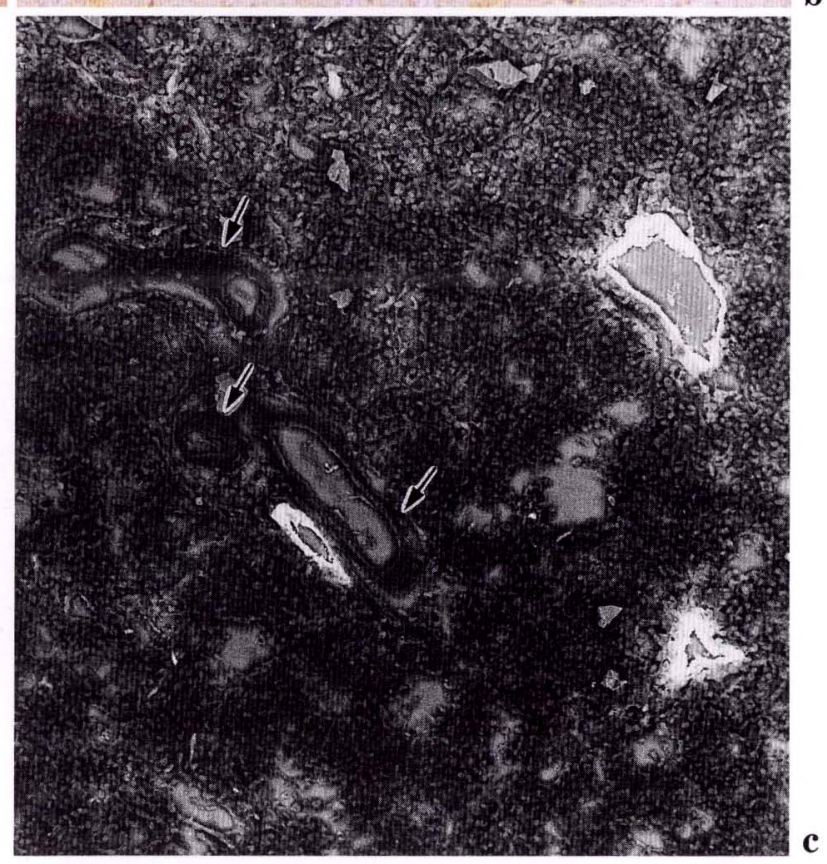



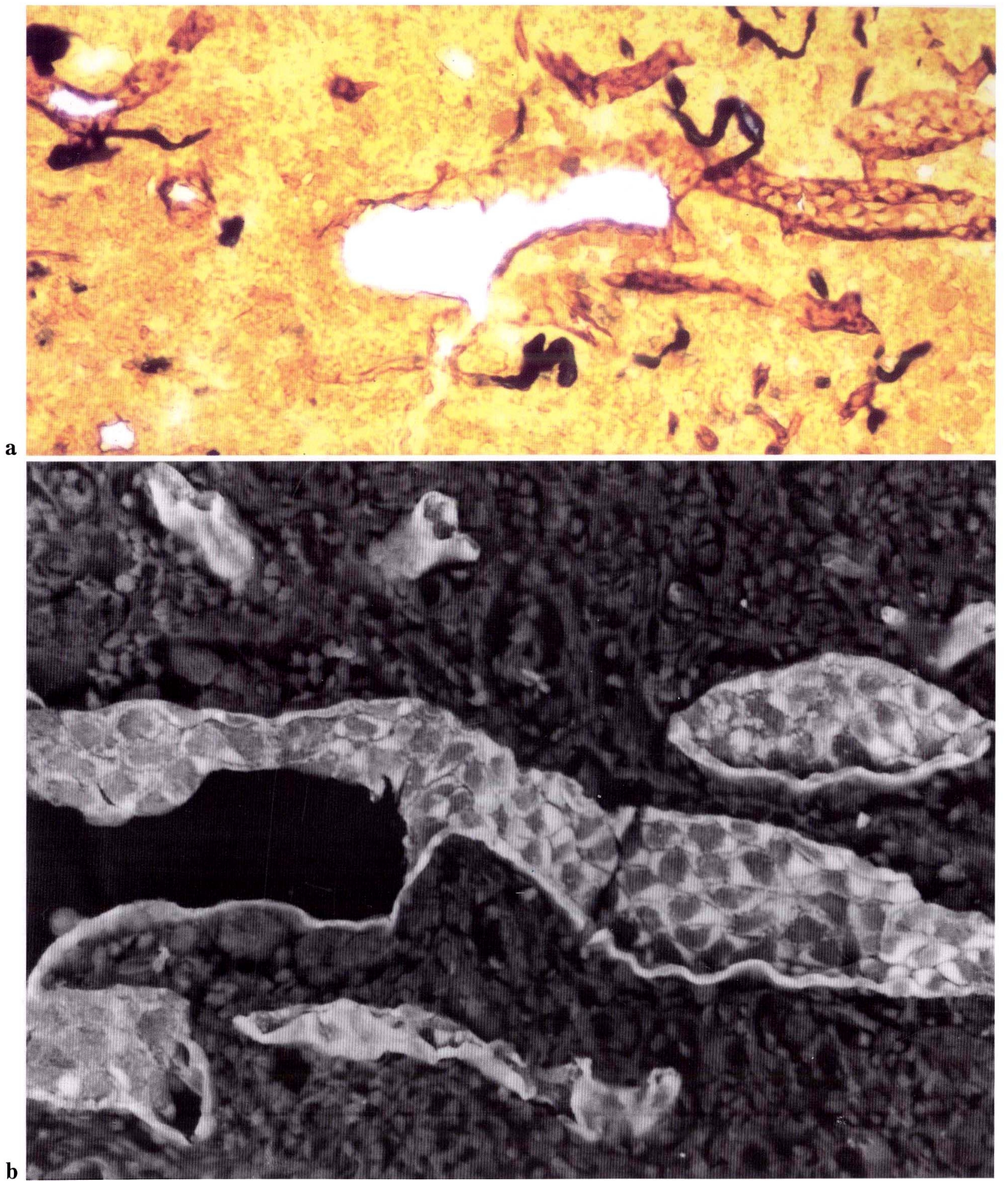

Fig. 2. Light (a) and BEI scanning electron (b) micrographs of a section $(20 \mu \mathrm{m})$ of another thymus. a. 5'-Nase (brown) and ALPase (dark blue) activity of lymphatics and blood vessels. Note the peculiar pattern of the staining of the $5^{\prime}$-Nase-positive lymphatic walls. The pattern suggests cellular contours. $\times 870$. b. BEI of the same section at a higher magnification. A pavement pattern of continguous endothelial cells is suggested. The bright areas show localization of the reaction product. $\times 2,700$ 

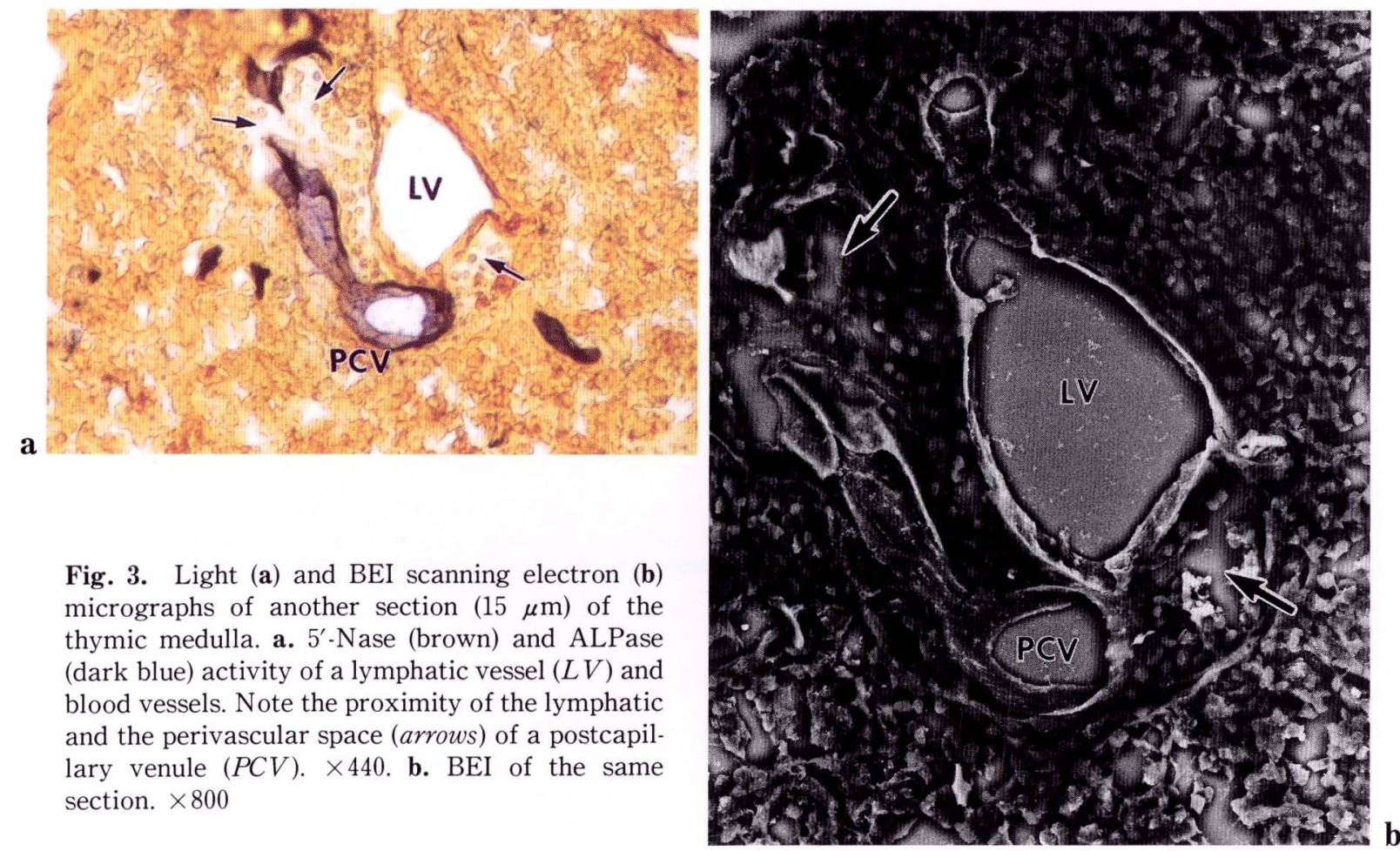

Fig. 3. Light (a) and BEI scanning electron (b) micrographs of another section $(15 \mu \mathrm{m})$ of the thymic medulla. a. 5'-Nase (brown) and ALPase (dark blue) activity of a lymphatic vessel $(L V)$ and blood vessels. Note the proximity of the lymphatic and the perivascular space (arrows) of a postcapillary venule $(P C V) . \times 440$. b. BEI of the same section. $\times 800$

\section{Backscattered and secondary electron images}

Backscattered electron images (BEIs) of the same sections as those used for the light micrographs (Figs. 1b, 2a, 3a) are illustrated in Figures 1c, 2b, 3b. Under the backscattered SEM, the reaction product of $5^{\prime}$ Nase activity highlights the wall of lymphatics. Figure $3 \mathrm{~b}$ also demonstrates a pattern of staining for $5^{\prime}$-Nase activity, which suggests a localization of the reaction product related to the contours of lymphatic endothelial cells. The secondary electron images (SEI) showed, to some extent, the three-dimensional structure of the lymphatics and blood vessels although there was a certain degree of damage to the surface morphology.

\section{Transmission electron microscopy (TEM)}

In the thymus injected with a colloidal carbon suspension into blood vessels, the lymphatic vessels were carbon-free-in contrast to the blood vessels which contained many granules. The reaction product of the $5^{\prime}$-Nase activity in the tissues incubated in the medium containing L-tetramisole was a dense granular precipitate localized on the cell surface of the lymphatic endothelium but not on the vascular en-

dothelium (Fig. 4a). The precipitate was associated with the outer surfaces of the lymphatic endothelial cell membranes and extended along overlapping and interdigitating cytoplasmic processes at cell junctions (Fig. 4b, c). The reaction product was also seen on the basal aspect of the endothelial surface. Lymphocytes, which were judged to be in various stages of migration across the lymphatic endothelium, were often observed by TEM; some of them were strongly $5^{\prime}$-Nase positive (Fig. $4 \mathrm{~b}$ ). In addition, the reaction product could also be detected on the cell surface of some thymic lymphocytes in the parenchyma. There was no reaction product in control sections.

\section{DISCUSSION}

The present study has demonstrated enzymehistochemically the existence of intralobular lymphatic vessels in the mouse thymus by the $5^{\prime}$-NaseALPase double staining method. This double staining method was first reported in lymphatics of the rat pharynx by WERNER, SCHÜNKE and TILLMANN (1987). They also showed light microscopically the sole visualization of $5^{\prime}$-Nase activity by inhibiting the 
a
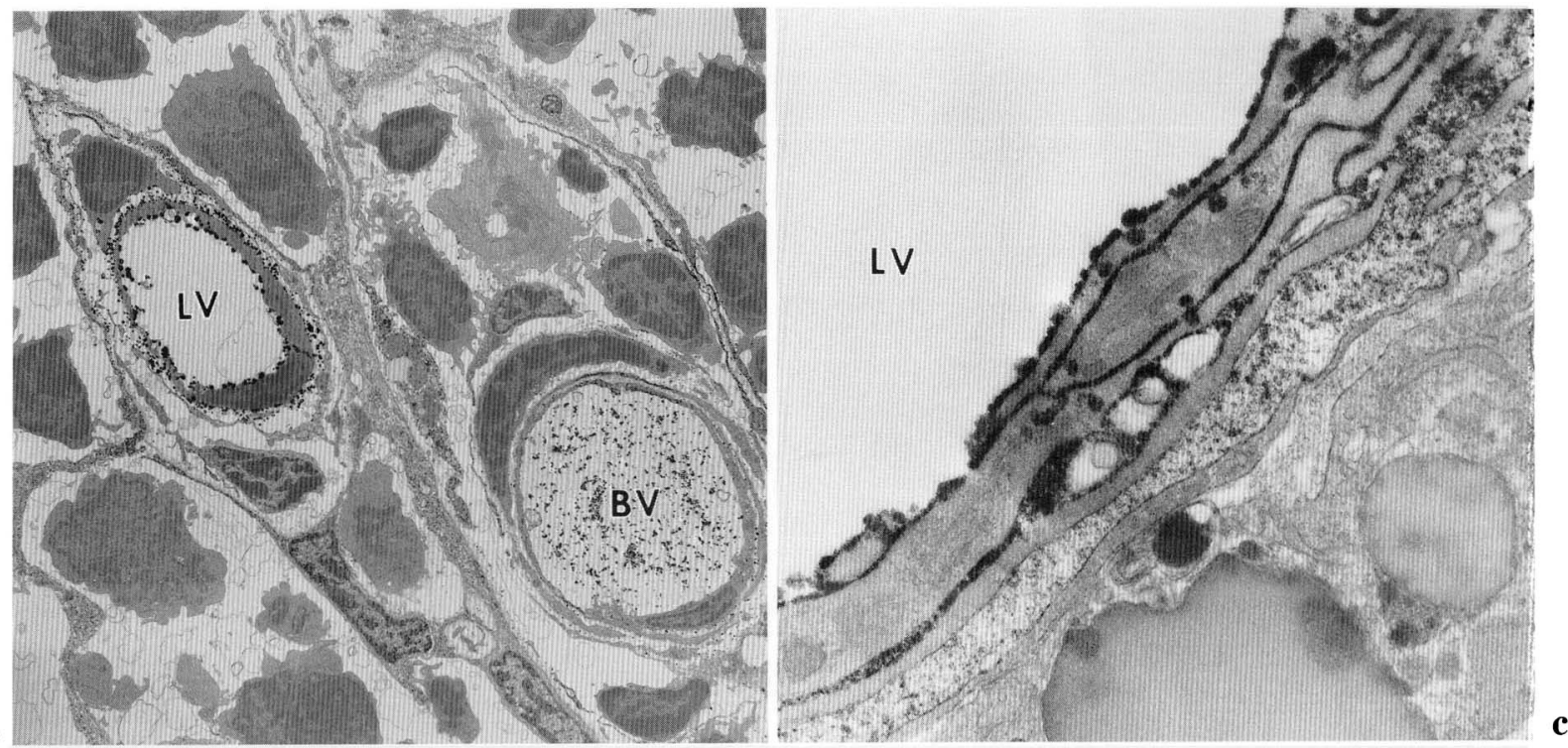

c

\section{b}

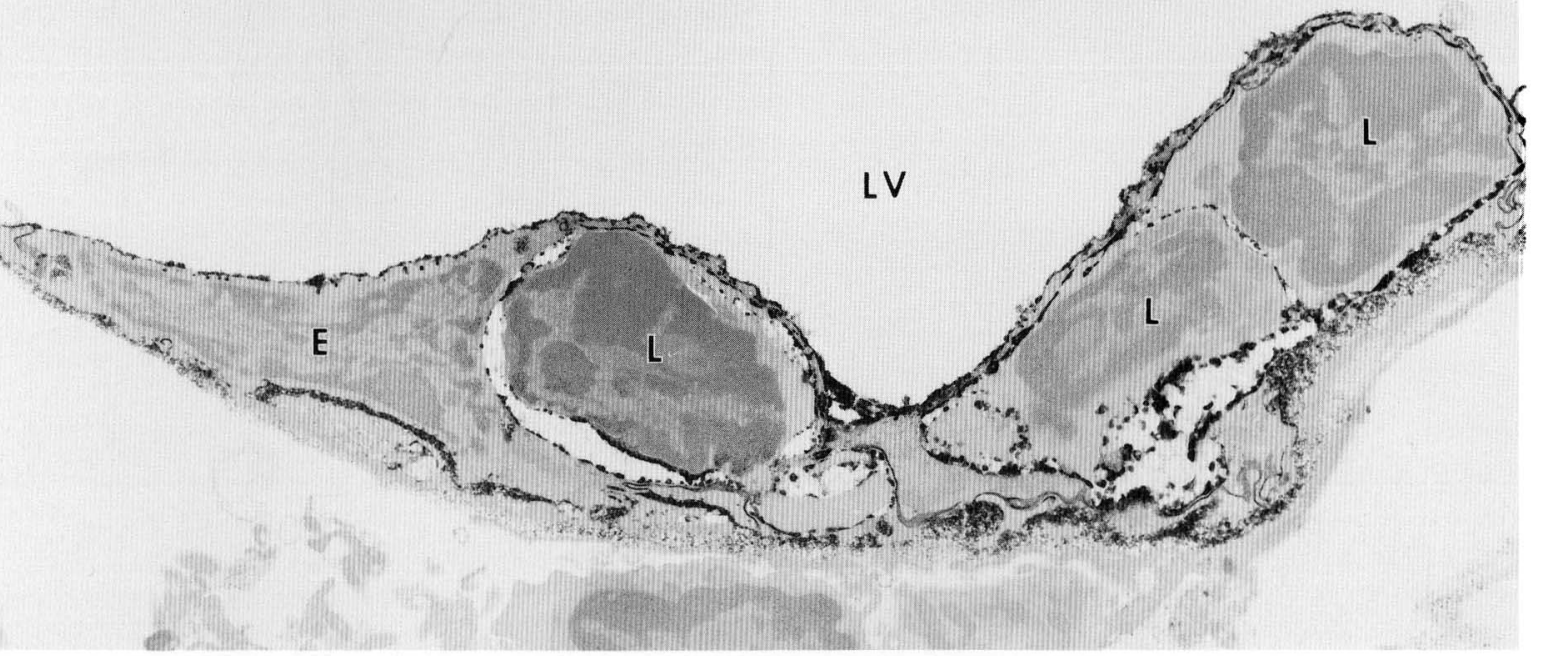

Fig. 4. Transmission electron micrographs of $5^{\prime}$-Nase-positive lymphatics and $5^{\prime}$-Nase-negative blood vessel. a. Lead-based $5^{\prime}$-Nase reaction of carbon-injected thymus. Note $5^{\prime}$-Nase reaction product associated with the carbon-free lymphatic vessel $(L V)$ but not with the blood vessel $(B V)$ containing carbon granules. $\times 2,700$. b. Lead-based $5^{\prime}$-Nase reaction. The dense granular precipitate is localization on the outer surface of cell membranes in the lymphatic wall and on the basal aspect of the endothelium. In addition, the cell surfaces of lymphocytes $(L)$, apparently in transit across the lymphatic endothelium, are $5^{\prime}$-Nase positive. $E$ endothelial cell. $\times 7,600$. c. Cerium-based $5^{\prime}$-Nase reaction. Dense granular reaction product is associated with the lymphatic endothelium. $\times 16,000$

nonspecific ALPase activity with L-tetramisole. The reaction product of $5^{\prime}$-Nase is associated only with lymphatic walls, thereby allowing this method for $5^{\prime}$-Nase to be used to distinguish them from blood vessels. As detailed previously (KATO and MiYAUCHI, 1989), phosphoric ions liberated during the $5^{\prime}$-Nase reaction are detected as precipitates of the brown or black lead sulfide when sections are immersed in an ammonium sulfide solution and examined under the light microscope. In the present study, furthermore, a backscattered electron image (BEI) was effectively applied to the same section to compare the localization of $5^{\prime}$-Nase with light and scanning electron microscopy. Bright highlights on the BEIs correspond to the brown or black coloration of the lymphatic walls due to the reaction product in light micro- 
graphs. The lead-based or cerium-based medium with L-tetramisole for TEM was used to demonstrate the ultrastructural localization of $5^{\prime}$-Nase activity in the lymphatic endothelium. L-tetramisole is considered to be effective for the specific reaction of $5^{\prime}$-Nase, because it exerts no influence on the 5'-Nase activity (De Pierre and Karnovskyy, 1974). Under the TEM, the reaction product of $5^{\prime}$-Nase activity is seen as dense granular precipitates on the cell surface of lymphatic endothelial cells. The reaction product coats the luminal cell surface, extends between overlapping and interdigitating cells at cell junctions, and is present in the subendothelial space.

In one instance, a $5^{\prime}$-Nase-positive lymphatic vessel was seen in the immediate vicinity of the perivascular space (PVS) around a postcapillary venule. The author has previously described a discrete opening in the lymphatic wall next to a PVS and interpreted it as a possible route for lymph and lymphocytes efflux into the lymphatic from the PVS (KATO, 1988). Such openings in the wall of lymphatic vessels have also been described in the rat thymus (KoTANI et al., 1967). Thus, $5^{\prime}$-Nase-positive lymphatic vessels in the present study have been interpreted as initial lymphatics, some of them very closely associated with the PVS.

An interesting observation was the frequent association of $5^{\prime}$-Nase activity with lymphocytes, which were judged to be in various stages of migration across the lymphatic endothelium. As to the relationship between $5^{\prime}$-Nase activity and subpopulations of lymphocytes, MUELLER-HERMELINK (1974) reported the presence of $5^{\prime}$-Nase-positive lymphocytes in the "bursa equivalent"-derived (B) lymphocyte-dependent area of lymph nodes. On the other hand, the activity of thymic lymphocytes has been described as significantly lower (UUSITALO and KARNOVSKY, 1977). Furthermore, on the basis of the difference between $5^{\prime}$-Nase activity in thymic lymphocytes and peripheral circulating thymus-derived (T) lymphocytes, EDWARDS et al. (1979) suggested that the expression of this enzyme may be linked to T-lymphocyte ontogeny and be a marker for post-thymic $\mathrm{T}$ lymphocytes. The subpopulation of $5^{\prime}$-Nase-positive lymphocytes remains, therefore, a controversial topic. Recently, OTSUKI and MAGARI (1988) and OTSUKI, ITO and MAGARI (1989) have demonstrated in immunoelectron microscopic studies that the largest subpopulation of recirculating lymphocytes in both high endothelial venules and lymphatic capillaries is comprised of $\mathrm{T}$ lymphocytes, followed by surface Immunoglobulin M- or A-positive cells in both gutand bronchus-associated lymphoid tissues. According to the majority of previous reports, including our results, it can be surmised that $5^{\prime}$-Nase activity may also be related to the maturation of thymic lymphocytes. However, no conclusion could be drawn from the present study as to the subpopulation of the $5^{\prime}$-Nase-positive lymphocyte migrating across the lymphatic endothelium in the thymus. Further examination is needed to acertain the relationship between $5^{\prime}$-Nase activity and subpopulations of lymphocytes. In conclusion, the present study shows that the use of $5^{\prime}$-Nase activity provides a satisfactory method to distinguish intralobular lymphatic vessels from blood vessels. The results are in accord with our previous report on initial lymphatics in the mouse thymus (KATO, 1988).

Acknowledgements. The author thanks Mr. M. GотоH (Application Technology Dept., Hitachi Instrument Engineering Co. Ibaraki) for his skilled technical assistance.

\section{REFERENCES}

Burstone, M. S.: Enzyme histochemistry and its application in the study of neoplasms. Phosphatase. Academic Press, New York, 1962 (p. 160-292).

De Pieree, J. W. and M. L. Karnovsky: Ecto-enzyme of granulocytes: 5'-Nucleotidase. Science 184: 1096-1098 (1974).

Edwards, N. L., E. W. Gelfand, L. Burk, H.-M. Dosch and I. H. Fox: Distribution of $5^{\prime}$-nucleotidase in human lymphoid tissues. Proc. Nat. Acad. Sci. 76: 3474-3476 (1979).

Heusermann, U.: Morphologie der Lymphgefäße, der Nerven, der Kapsel und der Trabekel der menschlichen Milz. Habilischr. Med. Fakultät, Kiel, 1979 (quoted from WERNER et al., 1987).

Hwang, W. S., T. Y. Ho, S. C. Luk and G. T. Simon: Ultrastructure of the rat thymus. A transmission scanning electron microscope, and morphometric study. Lab. Invest. 31: 473-487 (1974).

InouÉ, T. and H. OSATAKE: A new drying method of biological specimens for scanning electron microscopy. The t-butyl alcohol freeze-drying method. Arch. Histol. Cytol. 51: 53-59 (1988).

KAT0, S.: Intralobular lymphatic vessels and their relationship to blood vessels in the mouse thymus. Lightand electron-microscopy. Cell Tiss. Res. 253: 181-187 (1988).

- Enzyme-histochemical identification of lymphatic vessels. (In Japanese with English abstract). Jap. J. Lymphol. 12: 1-9 (1989).

-: Enzyme-histochemical identification of lymphatic vessels by light and backscattered image scanning electron microscopy. Stain Technol. 65 (1990, in press). 
Kato, S. and R. MiYauchi: Enzyme-histochemical visualization of lymphatic capillaries in the mouse tongue: Light and electron microscopic study. Okajimas Fol. Anat. Jap. 65: 391-404 (1989).

Kato, S. and G. I. Schoefl: The microvasculature of the normal and involuted mouse thymus: Light and electron microscopic study. Acta Anat. 135: 1-11 (1989).

Kotani, M., S. Seiki, A. Yamashita and I. HoriI: Lymphatic drainage of thymocytes to the circulation in the guinea pig. Blood 27: 511-520 (1966).

Kotani, M., Kawakita, M. Fukanogi, A. Yamashita , K. SeikI and I. HoriI: The passage of thymic lymphocytes to the circulation in the rat. Okajimas Fol. Anat. Jap. 43: 61-71 (1967).

MUELLER-HeRmelink, H. K.: Characterization of the B-cell and T-cell regions of human lymphatic tissue through enzyme histochemical demonstration of ATP ase and $5^{\prime}$-nucleotidase activities. Virchows. Arch. (B) Cell Pathol. 16: 371-378 (1974).

OMORI, H.: Finer distribution of the lymph vessels in the thymus. (In Japanese with English abstract) Acta Anat. Nippon. 48: 315-329 (1973).

OTSUKI, Y. and S. MAGARI: Lymphocyte subpopulations in high endothelial venules and lymphatic capillaries in rat Peyer's patches: An immunoelectron microscopic study. Acta Histochem. Cytochem. 21: 33-44 (1988).

OTsuki, Y., Y. Ito and S. MagaRI: Lymphocyte subpopulations in high endothelial venules and lymphatic capillaries of bronchus-associated lymphoid tissue (BALT) in the rat. Amer. J. Anat. 184: 139-146 (1989).

RoBInson, J. M. and M. J. KARNovsky: Ultrastructural localization of $5^{\prime}$-nucleotidase in guinea pig neutrophils based upon the use of cerium as capturing agent. J. Histochem. Cytochem. 31: 1190-1196 (1983).

Sмiтh, C.: Studies on the thymus of the mammal. VIII. Intrathymic lymphatic vessels. Anat. Rec. 122: 173-179 (1955).

UsHIKI, T.: A scanning electron-microscopic study of the rat thymus with special reference to cell types and migration of lymphocytes into the general circulation. Cell Tiss. Res. 244: 285-298 (1986).
Uusitalo, R. J. and M. J. KaRnovsky: Surface localization of $5^{\prime}$-nucleotidase on the mouse lymphocytes. J. Histochem. Cytochem. 25: 87-96 (1977).

VeTter, W.: Alkaline Phosphatasen in Mastzellen, Blutund Lymphgefäßen der Rattenzunge. 5'-Nucleotidase-, unspezifische alkalische Phosphatase- und Polyphosphatase-(ATP'ase) Aktivität unter besondere Berücksichtigung des pH. Z. Anat. Entw.-Gesch. 130: 153-176 (1970).

W achstein, M. and E. Meisel: Histochemistry of hepatic phosphatases at a physiologic $\mathrm{pH}$. Amer. J. Clin. Pathol. 130: 153-176 (1957).

Werner, J. A., M. Schünke and B. Tillmann: Histochemical visualization of lymphatic capillaries in the rat: A comparison of methods demonstrated at the posterior pharyngeal surface. Arch Histol. Jap. 50: 505514 (1987).

Wheeler, E. E., J. B. Gavin and R. N. Seelye: Freezedrying from tertiary butanol in the preparation of endothelium for scanning electron microscopy. Stain Technol. 50: 331-337 (1975). 